\title{
OCCURRENCE OF CHANCELLORIA WALCOTT IN THE COMLEY
}

\section{LIMESTONE}

SiR,-During sorting last year of material etched from the Comley Limestone, Professor Alwyn Williams of this department discovered a number of sponge spicules, which he referred to me for identification. These are mostly forms which seem to represent a species of the Heteractinellid Chancelloria Walcott. So far as I know, this Cambrian genus has not previously been recorded outside North America.

The spicules concerned are forms having seven, eight, or nine rays, in which six, seven, or eight rays are arranged in the manner of spokes of an umbrella in relation to the end of a shaft, formed by a further ray. In technical terms, they are hexaenes, heptenes, and otaenes, if the spokes and shaft are treated as cladi and a rhabdus (or rhabdome) respectively (by analogy with the Demospongid triaene: cf. de Laubenfels, 1955, p. E 93; Sollas, 1888, pp. lv-lvi and fig. xi). The spoke-like rays, or cladi, are swollen near their junctions with the rhabdus - or shaft-but markedly constricted at the point of junction, where a depressed suture is seen. The swollen bases of the cladi are in contact laterally, again with sutured junctions. The head of the rhabdus may itself be rather swollen. The cladi are often slightly curved, with the curvature, as in an umbrella, on the side which faces the shaft; the latter itself may be curved to one side. The cladal bases are flattened on the side opposite to the rhabdus; within the flattened areas there are traces of rounded depressions. On the head of the rhabdus, which is seen surrounded by the bases, a similar depression may occur. The length of the rays is ca. $0 \cdot 7-1 \cdot 5 \mathrm{~mm}$.

Regarding preservation, most of the spicules are siliceous, though finely roughened, greenish in colour, and doubly refractive. Some are, however, preserved as ferruginous pseudomorphs. Besides complete examples there are also fragments, consisting of portions of spicules which have broken along the sutures between the rays.

Many-rayed spicules of this general form, called umbrella spicules by Hinde (1887-1912), are among those which characterize the Heteractinellida. The features which point specially to Chancelloria are the sutured junctions of the rays, and the depressions on the head of the rhabdus and bases of the cladi. The umbrella spicules seen otherwise in Tholiasterella Hinde (ibid.)whose known occurrences, incidentally, are Carboniferous-do not show either of these features. Suturing of rays may occur in the Cambrian Eiffelia Walcott (Walcott, 1924, p. 324); but in this form the number of cladi is fixed at six, and there seem to be shaft rays on both sides of the spoke-like group of cladi. The spicules recorded here are most like those figured by Walcott from C. eros Walcott and C. drusilla Walcott (ibid., p. 86, figs. 2-2c, and pl. 87, figs. 2-2e); both of these show the depressions referred to, which seem to be lacking in Eiffelia. In possession of a definite rhabdus, in place of the central disc of $C$. eros, our spicules agree in particular with those of $C$. drusilla; but definite reference to this species would be premature at present.

Owing to the sutured junctions of the rays, the spicules give the impression not of normal many-rayed spicules but of aggregates of articulated ray-like bodies. The depressions first noted by Walcott, on the disc or the head of the rhabdus and on the bases of the cladi, are in themselves unusual. They might be analogous with the feature called the hilum in the Demospongid microscleres known as sterrasters; this is a depression which marks the position of the nucleus of the secretory cell (scleroblast) by which the spicule is produced (cf. Sollas, 1888, pp. lxiv-lxv and fig. xxi, $\pi$ ). Perhaps in Chancelloria we have a - possibly primitive-condition with each ray essentially independent and produced by a separate scleroblast, the position of whose nucleus is marked by a hilum-like depression.

\section{REFERENCES}

HINDE, G. J., 1887-1912. A Monograph of the British Fossil Sponges. Palaeont. Soc., London. 
Laubenfels, M. W. DE, 1955. Porifera. In Treatise on Invertebrate Paleonto$\log y$, Part E, 21-122.

Sollas, W. J., 1888. Report on the Tetractinellida collected by H.M.S. Challenger, during the years 1873-1876. Rep. Sci. Res. H.M.S. Challenger, xxv.

Walcotr, C. D., 1924. Middle Cambrian Spongiae. Smithsonian Misc. Coll., $67,261-364$.

DEPARTMENT OF GEOLOGY,

R. E. H. ReID.

THE QUEEN'S UNIVERSTTY OF BELFAST, BELFAST, NORTHERN IRELAND.

2nd March, 1959.

\section{REVIEWS}

The Earliest Geological Treatise (1667). By Nicolaus Steno. Translated with introduction and notes by AXEL GARBOE. 51 pp. with 4 plates. London: Macmillan, 1958. Price 15s.

A casual glance at the title of this book might lead one to suppose that it claims for Steno's work a position of unrivalled priority in the early literature of geology. Such a claim could hardly be justified. In fact, however, it is Steno's earliest work on geology that is reprinted here.

Steno was not the first to argue for the organic origin of fossils, but it is fair to say that none of his predecessors presented the case with greater skill. The " modernity" of his approach is remarkable. Instead of attempting, as many of his contemporaries did, to explain all geological phenomena in a single all-embracing system, he focused attention on a limited problemthe existence, in some rocks, of "bodies" with close resemblances to living organisms. First he presents a number of simple but perspicacious observations about these "bodies" and the rocks in which they occur. He follows these with a series of inferences, which are closely and persuasively argued, and arranged skilfully to lead the reader by successive steps to the final conclusion: that only the interpretation of the "bodies" as organic remains will serve to account for all the observations. This clear separation of observations from inferences is itself unusual for the period; and having postulated (on the evidence of the fossils) the former existence of the sea over areas that are now dry land, he did not feel bound to go on to justify this by a full-blown theory of earth movements. This work was originally published merely as an appendix to an anatomical description of a giant shark. This is significant: unlike many early geologists, Steno approached the problem of fossils through the study of anatomy, not mineralogy; and in this present work his critical evidence for his interpretation lies in the detailed resemblance between fossil "glossopetrae" and the teeth of the shark. Here, in the close comparison of fossils with living organisms, is the germ of palaeontological method.

This little work is one of the finest specimens of geological reasoning in the early history of the science. It is to be hoped that it will be widely read by geologists; for it may help to dispel the belief, still widespread, that those who wrote on geology before 1800 were all the credulous purveyors of quaint fables, prevented by innate stupidity from seeing what is patently clear to more enlightened generations.

In this attractively produced edition, the latin text and the translation are printed on alternate pages, facing one another. The translation is readable and accurate. Dr. Garboe also provides a useful introduction to the work. It is a pity that this interesting, but very slim, volume should be so expensive.

M. J. S. R. 